\title{
Identification of cowpea genotypes for drought tolerance ${ }^{1}$
}

\author{
Identificação de genótipos de feijão-caupi tolerantes à seca
}

\author{
Edson Alves Bastos ${ }^{2 *}$, Sebastião Pereira do Nascimento ${ }^{3}$, Everaldo Moreira da Silva ${ }^{4}$, Francisco Rodrigues \\ Freire Filho ${ }^{5}$ e Reinaldo Lúcio Gomide 6
}

\begin{abstract}
The genotypes selection for drought tolerance is very important for world food production, principally in arid regions or sites with irregular rain distribution. The objective of this work was to identify cowpea genotypes with drought tolerance and water stress sensitivity characteristics. Two experiments were carried out with 20 treatments and four replications, one under water deficit during reproductive phase and another one under full irrigation. The water deficit was obtained applying half the water depth required by cowpea. The leaf area index, chlorophyll content, grain components and grain yield were evaluated. The water deficit reduced $20 \%$ the leaf area index, $16 \%$ the chlorophyll content, $175 \%$ the pod number per plant and $60 \%$ the grain yield. The genotypes Santo Inácio and Tracuateua-192 present sensitivity to water deficit in soil and BRS-Paraguaçu, Pingo-de-ouro-1-2 and Pingo-de-ouro-2 show behavior for drought tolerance.
\end{abstract}

Key words - Vigna unguiculata. Leaf area index. Chlorophyll content.

Resumo - A seleção de genótipos com tolerância à seca é essencial para a produção de alimentos no mundo, especialmente em regiões de clima árido ou com má distribuição de chuvas. Nesse contexto, o objetivo deste trabalho foi identificar genótipos com características de tolerância e sensibilidade ao estresse hídrico. Foram conduzidos dois experimentos em campo, um sob déficit hídrico durante a fase reprodutiva e outro sob irrigação plena, ambos em um delineamento de blocos ao acaso com 20 tratamentos (genótipos) e quatro repetições. O déficit hídrico foi obtido aplicando-se, aproximadamente, metade da lâmina requerida pela cultura do feijão-caupi. Foram avaliados o índice de área foliar, teor de clorofila, componentes de produção e o rendimento de grãos. O déficit hídrico reduziu em $20 \%$ o índice médio de área foliar, $16 \%$ o índice médio de clorofila, $175 \%$ o número médio de vagens por planta e em $60 \%$ a produção de grãos. Os genótipos Santo Inácio e Tracuateua-192 são sensíveis ao déficit de água no solo, enquanto o BRS-Paraguaçu, o Pingo-de-ouro-1-2 e o Pingo-de-ouro-1 são tolerantes à seca.

Palavras-chave - Vigna unguiculata. Índice de área foliar. Teor de clorofila.

\footnotetext{
*Autor para correspondência

${ }^{1}$ Recebido para publicação em 11/05/2010; aprovado em 12/10/2010

Financiada pelo Generation Challenge Program, parte da Dissertação de Mestrado do segundo autor

${ }^{2}$ Pesquisador da Embrapa Meio-Norte, Área de Irrigação e Drenagem, Teresina-PI, Brasil, (86) 3089-9100, Ramal 159, edson@cpamn.embrapa.br

${ }^{3}$ Instituto Federal de Educação Ciência e Tecnologia do Piauí, Corrente-PI, Brasil, (89) 3573-2620, spnascimento@ifpi.edu.br

${ }^{4}$ Mestrando, ESALQ/USP, Área: Irrigação e Drenagem, Piracicaba-SP, Brasil, (19) 3447-8561 Ramal: 8561, everaldo@usp.br

${ }_{5}^{5}$ Pesquisador da Embrapa Meio-Norte, Área de Genética Vegetal, Teresina-PI, Brasil, (86) 3089-9100, Ramal 158, freire@cpamn.embrapa.br

${ }^{6}$ Pesquisador da Embrapa Milho e Sorgo, Área de Irrigação e Drenagem, Sete Lagoas-MG, Brasil, (31) 3027-1328, Ramal 1828, gomide@cnpms. embrapa.br
} 


\section{Introduction}

The cowpea is grown in almost throughout the Northeast under drought and, therefore subject to water scarcity due to poor rainfall distribution. In Piauí, the situation is similar and according to Conab (2008), this state is the second greatest producer of cowpea in the Northeast with 230,900 ha and production of $82,600 \mathrm{t}$; but its productivity is the lowest in the region, reaching only $358 \mathrm{~kg} \mathrm{ha}^{-1}$. According to Mousinho (2006), the cowpea sensitivity to water scarcity in the soil, together with climatic uncertainties, mainly related to the irregular rainfall distribution from one year to another and from one place to another, determine these low income and the oscillation in the annual crop production in Piauí.

The water deficit is one of the major causes of reduction in agricultural productivity, primarily by affecting all aspects related to the plant development, including anatomical, morphological, physiological and biochemical modifications, being the losses directly related to its duration, severity and stage of crop development (BEZERRA et al., 2003).

The leaf area is related to the plant's metabolism, dry matter production and yield (SEVERINO et al., 2004), being an important production factor and measurement of water use plants when exposed to water deficit (FERNÁNDEZ et al., 1996; VIEIRA et al., 2000). Such situation was also observed by Ribeiro et al. (2004), Matsui and Singh (2003) in cowpea researches. According to Netto et al. (2005), the indirect determination of chlorophyll content in leaves can be used as a tool to diagnose the integrity of the photosynthetic apparatus when the plants are subjected to environmental adversity.

The plant tolerance to water deficit is an important defense to keep the production process in conditions of low water availability. In semi-arid areas, subject to more irregular rainfall distribution and occurrence of long summer, it should be recommended the use of more rustic cultivars, tolerant to water stress and with greater ability to recover after a drought. According to Ribeiro et al (2004) the cowpea is more resistant to drought than the common bean. Hence the reason it be grown in most countries from tropical regions.

In this context the present study evaluated the effect of water deficit in cowpea during the reproductive phase, aiming to identify genotypes tolerant to drought based on determinations of leaf area index, chlorophyll content, production components and grain yield in conditions of soil and climate of Teresina, PI.

\section{Material and methods}

Two experiments were conducted during the reproductive phase of cowpea, one with full irrigation and the other with water deficit, both in the experimental field of Empresa Brasileira de Pesquisa Agropecuária, Embrapa Meio-Norte located in Teresina, PI, Brazil $\left(05^{\circ} 05^{\prime}\right.$ South latitude, $42^{\circ} 48^{\prime}$ ' West longitude and $74.4 \mathrm{~m}$ altitude) from August to October, 2008. The climate of the municipality is Aw (tropical climate of wet and dry seasons), according to Köppen classification. The annual averages of relative humidity and rainfall are $72.6 \%$ and $1,336 \mathrm{~mm}$, respectively, concentrating most of the rainfall between January and April (BASTOS; ANDRADE JÚNIOR, 2009). The monthly mean values for maximum, average and minimum air temperature from August to October were $36.6 ; 29$ and $21.9{ }^{\circ} \mathrm{C}$, respectively, and the average relative humidity and total rainfall between these months were $53 \%$ and $9 \mathrm{~mm}$, respectively.

The soil of experimental area is a Yellow Ultisol of Franco-sandy texture. Soil chemical analysis to the depth between $0-45 \mathrm{~cm}$ showed on average: Soil density $=1.36 \mathrm{~kg} \mathrm{dm}^{-3}, \mathrm{pH}$ in water $(1: 2,5)=5.24, \mathrm{P}=$ $2.50 \mathrm{mg} \mathrm{dm}^{-3} ; \mathrm{K}^{+}=0.10 \mathrm{cmol} \mathrm{dm}^{-3}, \mathrm{Ca}^{2+}=1.92 \mathrm{cmol}$ $\mathrm{dm}^{-3} ; \mathrm{Mg}^{2+}=0.79 \mathrm{cmol}_{\mathrm{c}} \mathrm{dm}^{-3}, \mathrm{Na}^{+}=0.19 \mathrm{cmol}_{\mathrm{c}} \mathrm{dm}^{-3}$, $\mathrm{H}^{+}+\mathrm{Al}^{3+}=3.29 \mathrm{cmol}_{\mathrm{c}}^{\mathrm{c}} \mathrm{dm}^{-3} ; \mathrm{CTC}=6.28 \mathrm{dm}^{-3}, \mathrm{~V}=$ $49.40 \%$. The soil analysis showed the need for acidity correction and the liming was based on the method of base saturation.

The experimental design was randomized blocks with 20 treatments and four replications. The treatments were constituted of 20 genotypes, namely Pitiúba, Tvu 36, TE-898, Capela, Canapuzinho, Canapu-BA, CanapuzinhoPE, CNCX 689-128G, BR17-Gurguéia, BRS-Paraguaçu, Patativa, (TE96-290-12G) cv. BRS Xiquexique, Pingo-de-ouro-1, Pingo-de-ouro-2, Pingo-de-ouro-1-2, Canapuzinho-2, EPACE-10, IPA-206, Tracuateua-192 and Santo Inácio. The seeds were acquired from the Embrapa Meio-Norte's germplasm bank.

The plots consisted of an area with $3.20 \mathrm{~m} \times 5.0 \mathrm{~m}$, totaling $16 \mathrm{~m}^{2}$, composed of four rows of plants arranged in a spacing of $0.8 \mathrm{~m} \times 0.25 \mathrm{~m}$. Four seeds per hill were manually planted on August, $6^{\text {th }} 2008$, with the thinning being performed 15 days after sowing (DAS), leaving two plants per hole, totaling a final stand of 100,000 plants per hectare. The floor area for data collection consisted of two central rows. Fertilization consisted of applying $20 \mathrm{~kg} \mathrm{ha}^{-1}$ $\mathrm{N}, 40 \mathrm{~kg} \mathrm{ha}^{-1}$ of $\mathrm{P}_{2} \mathrm{O}_{5}$ and $30 \mathrm{~kg} \mathrm{ha}^{-1}$ of $\mathrm{K}_{2} \mathrm{O}$ on plantation. During the experiment, several cultural treatments were performed in order to keep the area free of weeds, pests and diseases. At the 22 and $30 \mathrm{DAS}$, a leaf fertilizer consisting of macro and micronutrients (Niphokan to 1\%) was applied for good development of shoots. 
The irrigation was performed by a fixed conventional sprinkler system with sprinklers spaced at $12 \mathrm{~m} \mathrm{x} 12 \mathrm{~m}$, with nozzles of $3.4 \mathrm{~mm} \times 2.6 \mathrm{~mm}$ in diameter and flow rate of $1.07 \mathrm{~m}^{3} \mathrm{~h}^{-1}$ at a service pressure of 20 m.c.a. The calculation of these slides were carried out based on the reference of estimated evapotranspiration by Penmam-Monteith and the crop coefficients $(\mathrm{Kc})$ by phenological stage obtained by Ferreira et al (2008) for local soil climate conditions. The climatological data used to estimate the ETo were obtained in an automatic agrometeorological station about $500 \mathrm{~m}$ away from the experimental area. The soil's water content was monitored daily by the capacitance probe Divine $2000^{\circledR}$ in layers from $0.10 \mathrm{~m}$ to $0.70 \mathrm{~m}$ depth from the 25 DAS until the crop's cycle end. The value of field capacity $(-10 \mathrm{kPa})$ considering the layer from 0 to $0.45 \mathrm{~m}$ was $21.0 \%$ and the permanent wilting point $(-1,500 \mathrm{kPa})$ of $9.0 \%$ based on volume.

The leafarea index (LAI) estimated by the average of four radiation readings (one above and three below the canopy) was weekly determined from the 16 DAS with a ceptometer (LAI-2000 Plant Canopy Analyzer - Li-Cor) in each plot. The relationship between the incident light upon the crop and under the canopy of plants provides the transmittance of each angle, which is inversely proportional to the LAI (HOFFMANN; BLOMBERG, 2004). In addition, chlorophyll content of plants was monitored through the clorofiLOG electronic meter, model $1030 \mathrm{CFL}$. The measures of total chlorophyll content (ICF) were performed weekly throughout the crop cycle, taking leaves of two plants marked with and without water stress in each plot of the experiments (FALKER, 2008).

At harvest, it was determined: number of pods per plant (NPP), number of grains per pod (NGV), one hundred grains mass (GCM) and grain yield (PG), correcting the weight to $13 \%$ humidity. The results were submitted to analysis of variance, performing means comparinsons by the Scott-Knott test at $5 \%$ probability, using the program $\mathrm{SAEG}^{\circledR}$ 9.0/UFV.

\section{Results and discussion}

The water deficit was imposed between 33 and 44 DAS. In Figure 1, it is shown that variations in soil moisture under the two irrigation schemes were similar (between 21 and $15 \%$ in volume) until the 33 DAS, when of this date, soil moisture under water stress condition was below $15 \%$.

In the experiment without water deficit, the average soil moisture was $17.30 \%$, and ranged between 21

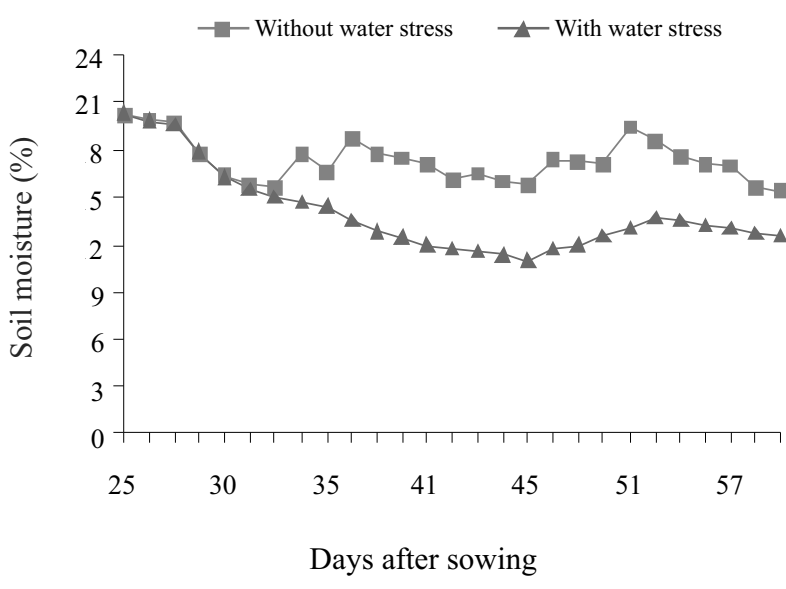

Figure 1 - Change in mean soil moisture to a depth of $0.70 \mathrm{~m}$, along the phenological cycle of the genotypes of cowpea, with and without water stress, during the period August-October 2008

and $15 \%$ during the crop cycle. This lowest soil moisture value corresponded to a critical tension of $-52 \mathrm{kPa}$. For cowpea, according to Gomes Filho and Tahin (2002), the maximum stress or the minimum moisture content in which the crop responds with optimum income is higher than $50.0 \mathrm{kPa}$, with the more negative tensions from this point representing the water deficit to the crop. In the stressed condition (FIG. 1) there is a reduction in soil moisture from the 33 DAS, the beginning of water stress imposition. Consequently, there was average variation of $14.0 \%$ in soil moisture for the entire crop cycle, reaching a critical value of $11.5 \%$ at the $44 \mathrm{DAS}$, end of water deficit. This low soil moisture value under drought stress corresponded to a critical tension of $-282 \mathrm{kPa}$. Irrigation was resumed from the 44 DAS increasing water content in soil by $15 \%(-52 \mathrm{kPa})$. It was observed that the tension in full irrigation condition remained above the critical moisture range, where there would be the soil water deficit. In the experiment with water suppression, the critical tension decreased with water deficit the imposition and remained below the threshold tension $(-50 \mathrm{kPa})$ until the end of cycle, forming a moderate water stress. Considering the level of soil's water depletion, it was found that the critical stress corresponded to a maximum consumption of 50 and $80 \%$ of water available in the soil for the experiments with and without water deficit, respectively.

The average values of leaf area index (LAI) are represented in Figure 2. The genotypes studied had their LAI's reduced in bloom by the water deficit imposition, with an overall average reduction of $28 \%$. Similar result were obtained by, Matsui and Singh (2003). According to Taiz and Zeiger (2004), there is a close relationship between the water availability in the soil and leaf area, being lower the leaf growth with 


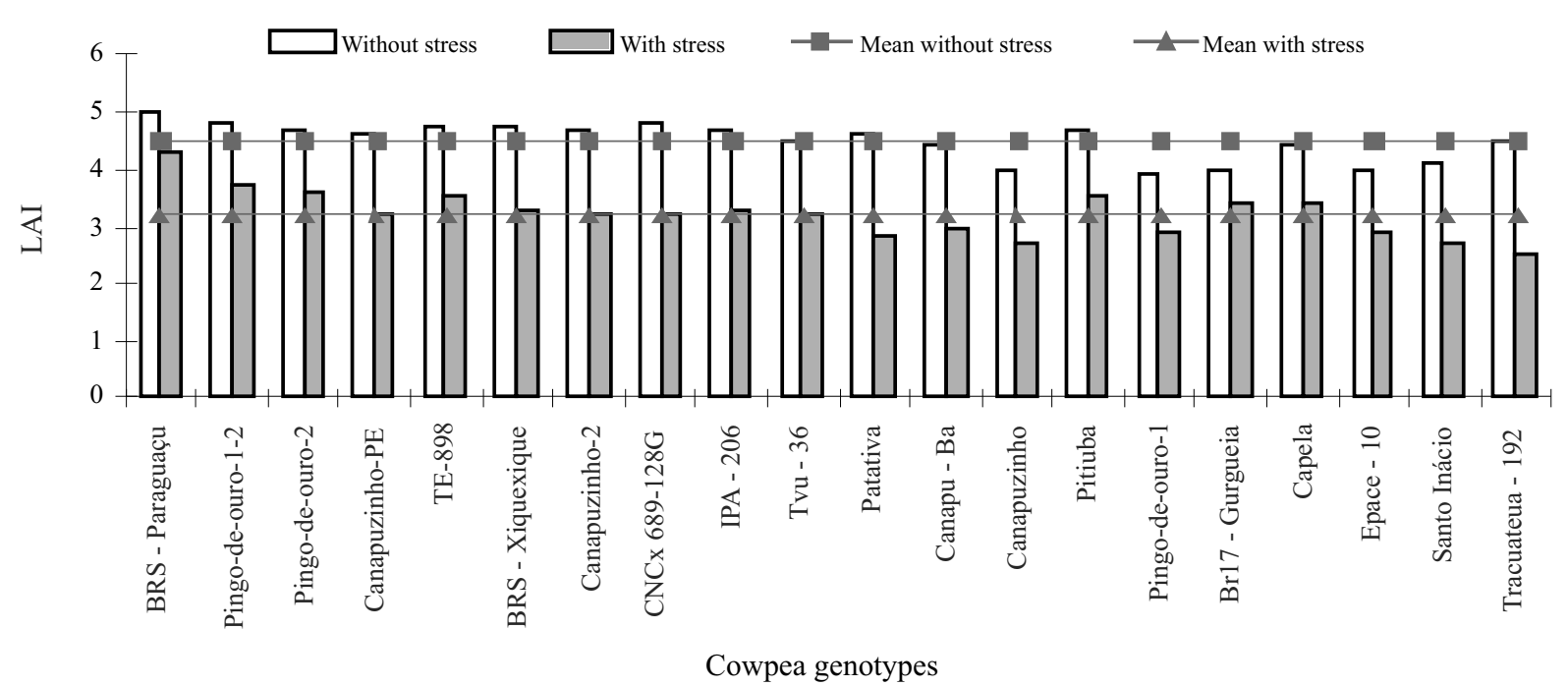

Figure 2 - Leaf area index (LAI) maximum and average of 20 genotypes of cowpea subjected to water stress during the reproductive phase, for the conditions with and without water stress, during the period August-October 2008

reduction of soil moisture, suggesting high sensitivity of this variable to water deficit.

The maximum LAI was 5.0 for the genotype BRSParaguaçu under conditions of full irrigation; the lowest was 3.9 for the Pingo-de-ouro-1 and the average value obtained during the whole crop cycle was 4.5. These results were superior to those obtained by Bastos et al. (2002), who found maximum LAI values ranging from 3 to 4.3 for the variety of cowpea BR 14-Mulato, and LAI of 3 for BR17-Gurguéia at the 47 days after sowing. However, Lima Filho (2000) found LAI of 2.8 for Pitiúba. These high LAIs found in this study should be result of the foliar implementation of macro and micronutrients during crop cycle, thus promoting greater leaf area expansion.

When evaluating the treatment under water deficit, there were maximum, minimum and average LAI values of $4.3 ; 2.5$ and 3.2, respectively. Seven genotypes showed LAI above the overall average. Genotypes BRSParaguaçu, Pingo-de-ouro-2 and Pingo-de-ouro-1-2 had the highest LAI, both in good condition and under water deficit. Similar results were observed in common-bean by Summerfield et al. (1985), which found that the most tolerant cultivar to drought, Negro Argel, showed greater maintenance of leaf area under water deficit, resulting in greater productivity. The reduction in leaf area under water deficit in plants can result in a survival strategy in order to reduce the area available for transpiration (CORREIA; NOGUEIRA, 2004).

Based on the considerations above, it seems consistent to say that water deficit imposed in reproductive phase allowed that leaf area reduction was activated in all genotypes. However, the highest LAI reductions were observed in the genotypes CNCX-689-128, Santo Inácio, Patativa and Tracuateua-192, which were reduced by $33 ; 34 ; 39$ and $44 \%$ respectively. Resulting, naturally, in reductions of the photosynthetic active area and hence grain yield. This observation is consistent with the results of Mendes et al. (2007), which showed that the ability of leaf area to support grain production has decreased significantly in the cultivars Epace-10 and Seridó when water deficit was applied to the reproductive phase. This reduction is a morphological defense mechanism, because the reduction in the water-plant-atmosphere interface decreases the transpiration, which is positive, but also reduces photosynthetic assimilation, which is negative for production. With smaller leaf area, there is transpiration decrease keeping the water in soil for a longer period (TAIZ; ZEIGER, 2004). According to Fernández et al. (1996), the water use by plants is determined by leaf area and, once exposed to water deficit it is reduced.

Regarding the total chlorophyll content (ICF), it was found that the reduction in soil water availability led to decreases in chlorophyll levels of leaves in 20 genotypes (FIG. 3). There was an overall average reduction of 19\% in the ICF in plants that have suffered the water deficit imposition. These results differ from those obtained by Lima (2008), who did not record significant changes in ICF likely to correlate with the water deficit effects. This author found that the cultivars of the species $V$. unguiculata showed ICF slightly higher than those observed in cultivars of $P$. vulgaris, which can be correlated with the highest rates of liquid photosynthesis observed in cowpea when compared with the common bean. However these ICF 


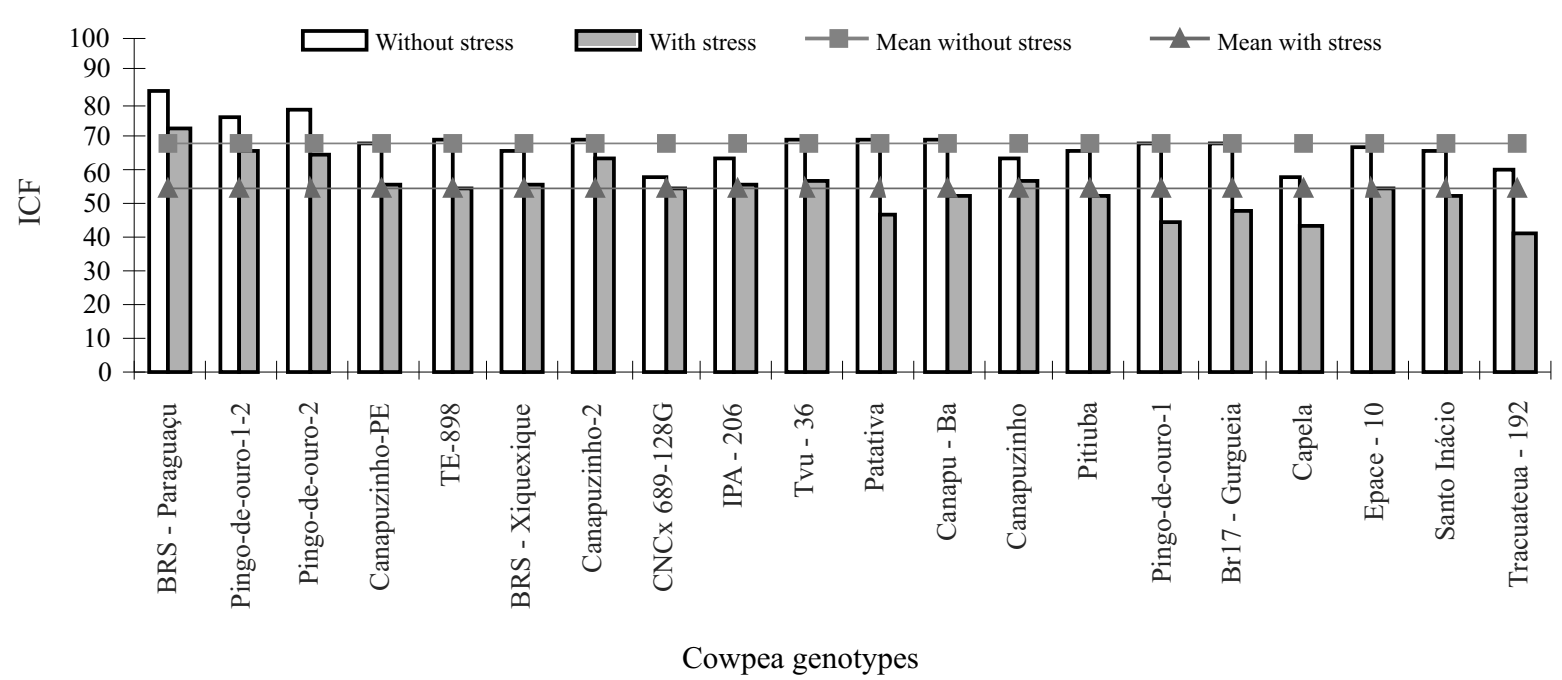

Figure 3 - Index of total chlorophyll (ICF) maximum and average of 20 genotypes of cowpea subjected to water stress during the reproductive phase, for the conditions with and without water stress, during the period August-October 2008

results were similar to those obtained by Gonçalves (2008) in sugar cane under severe stress (80\% water depletion), who found $19.6 \%$ reduction. However, it was less than that obtained by Cruz (2006) in maize, who found over 30\% reduction in total chlorophyll content in green house.

The ICF's (chlorophyll a + chlorophyll b) of the genotypes under full irrigation had maximum, minimum and average values of $83 ; 58$ and 68 , respectively, with variation of $30 \%$ between the highest and lowest ICF. While under water stress conditions these maximum, minimum and average ICFs were 73,42 and 55, respectively; resulting in $43 \%$ variation. The genotype CNCX 689$128 \mathrm{G}$ had the lowest average reduction in mean ICF, reaching only $6 \%$. This minor reduction of the ICF when the water deficit was imposed to the water deficit, it did not result in higher $\mathrm{PG}$, but classified it in the group of genotypes with intermediate grain yield. This result is due to the low ICF presented under conditions of adequate water supply. Furthermore, the genotype Pingo-de-ouro-1 showed the greatest decrease in the ICF (34\%). However, the grain yield was not the most affected possibly due to a lower reduction $(68 \%)$ in the number of pods per plant than in the genotype Tracuateua-192 which presented $86 \%$ reduction in the ICF; which reflected in high grain yield reduction. The genotypes that presented the highest grain yield had average reduction of only 12 and $13 \%$ in the ICF (BRS-Paraguaçu and Pingo-de-ouro1-2).

In turn, the behavior of genotypes analyzed separately were differentiated on the ICF. The genotypes BRS-Paraguaçu, Pingo-de-ouro-1 and Pingo-de-ouro1-2 showed greater stability in the ICF as markedly characteristic since the plants subjected to water stress present similar behavior to that under full irrigation, presenting value superior to the other genotypes.

The response provided by the genotypes above on the ICF can be an important feature, once they can increase their efficiency in the absorption of solar radiation, consequently higher photosynthetic rate, resulting in turn in higher grain yields.

Table 1 shows the mean number of pods per plant (NPP), number of grains per pod (NGP), one hundred grains mass (HGM) and grain yield (GY) under two water regimes (with water stress and without water stress). There was significant differences among genotypes for all these variables, except for NGV in the experiment under stress conditions. The water deficit determined reductions in the number of pods per plant and grain yield of all treatments. These results are in agreement with those obtained by Carvalho et al. (2000), when studying the water deficit effect on cowpea yield in the greenhouse found that the grain yield and number of pods per plant were reduced with the increase of water deficit, regardless of the phenological stages in which this occurred.

The variable NPP was much affected by the level of water stress applied and with more severity than that occurred in other components of production. It was observed that NPP has an average of $175 \%$ when the imposition of water deficit. This NPP reduction is associated with the flowers abortion caused by water deficiency in soil, which is in agreement with the results obtained by Nascimento et al. (2004) and Mendes et al. (2007) when studying variations on the levels of available water in soil on cultivars of cowpea found that for levels 
Table 1 - Means values ${ }^{1}$ for the number of pods per plant (NPP), number of grains per pod (NGP), hundred grains mass (HGM) and grain yield (GY) of 20 genotypes of cowpea under two water regimes

\begin{tabular}{|c|c|c|c|c|c|c|c|c|}
\hline \multirow{2}{*}{ Genotypes } & \multicolumn{2}{|c|}{-----------NPP---------- } & \multicolumn{2}{|c|}{-----------NGP---------- } & \multicolumn{2}{|c|}{--------HGM (g)-------- } & \multicolumn{2}{|c|}{------GY $\left(\mathrm{kg} \mathrm{ha}^{-1}\right)$------- } \\
\hline & $* \mathrm{NS}$ & "WS & NS & WS & NS & WS & NS & WS \\
\hline BRS- Paraguaçu & $10,9 \mathrm{a}$ & $4,3 \mathrm{a}$ & $16,9 \mathrm{a}$ & $13,2 \mathrm{a}$ & $16,8 \mathrm{~b}$ & $20,4 \mathrm{~b}$ & $1529 \mathrm{a}$ & $712 \mathrm{a}$ \\
\hline Pingo-de-ouro-1-2 & $8,1 \mathrm{~b}$ & $3,3 \mathrm{a}$ & $15,2 \mathrm{a}$ & $13,4 \mathrm{a}$ & 23,4 a & $27,5 \mathrm{a}$ & $1500 \mathrm{a}$ & 667 a \\
\hline Pingo-de-ouro-2 & $6,6 \mathrm{c}$ & $3,1 \mathrm{a}$ & $15,3 \mathrm{a}$ & $13,5 \mathrm{a}$ & $22,5 \mathrm{a}$ & $24,9 \mathrm{a}$ & $1236 \mathrm{a}$ & $642 \mathrm{a}$ \\
\hline Canapuzinho-PE & $7,1 \mathrm{c}$ & $3,2 \mathrm{a}$ & $16,0 \mathrm{a}$ & $13,6 \mathrm{a}$ & $22,2 \mathrm{a}$ & $23,4 \mathrm{a}$ & $1230 \mathrm{a}$ & $584 \mathrm{a}$ \\
\hline TE-898 & $6,4 \mathrm{c}$ & $2,7 \mathrm{~b}$ & $15,7 \mathrm{a}$ & $11,7 \mathrm{a}$ & $20,0 \mathrm{a}$ & $23,2 \mathrm{a}$ & $1023 \mathrm{~b}$ & $562 \mathrm{a}$ \\
\hline BRS Xiquexique & $9,0 \mathrm{~b}$ & $3,8 \mathrm{a}$ & $15,2 \mathrm{a}$ & $12,2 \mathrm{a}$ & $17,0 \mathrm{~b}$ & $19,5 \mathrm{~b}$ & $1245 \mathrm{a}$ & $538 \mathrm{a}$ \\
\hline Canapuzinho-2 & $8,0 \mathrm{~b}$ & $3,2 \mathrm{a}$ & $16,2 \mathrm{a}$ & $13,1 \mathrm{a}$ & $22,5 \mathrm{a}$ & $24,7 \mathrm{a}$ & $1380 \mathrm{a}$ & $533 \mathrm{a}$ \\
\hline CNCx 689-128G & $8,6 \mathrm{~b}$ & $3,2 \mathrm{a}$ & $15,4 \mathrm{a}$ & $12,6 \mathrm{a}$ & $18,7 \mathrm{~b}$ & $18,7 \mathrm{~b}$ & 1408 a & $520 \mathrm{a}$ \\
\hline IPA-206 & $8,2 \mathrm{~b}$ & $3,4 \mathrm{a}$ & $16,0 \mathrm{a}$ & $12,6 \mathrm{a}$ & 20,9 a & $23,0 \mathrm{a}$ & $1194 \mathrm{a}$ & $504 \mathrm{a}$ \\
\hline Tvu 36 & $11,2 \mathrm{a}$ & $4,3 \mathrm{a}$ & $16,4 \mathrm{a}$ & $14,7 \mathrm{a}$ & $13,8 \mathrm{c}$ & $14,1 \mathrm{c}$ & $1074 \mathrm{~b}$ & $494 \mathrm{a}$ \\
\hline Patativa & $7,6 \mathrm{c}$ & $3,0 \mathrm{a}$ & $14,1 \mathrm{~b}$ & $12,9 \mathrm{a}$ & $22,3 \mathrm{a}$ & $23,0 \mathrm{a}$ & $1107 \mathrm{~b}$ & $480 \mathrm{a}$ \\
\hline Canapu-Ba & $6,4 \mathrm{c}$ & $2,7 \mathrm{~b}$ & $15,6 \mathrm{a}$ & $13,2 \mathrm{a}$ & $23,4 \mathrm{a}$ & $22,8 \mathrm{a}$ & $1073 \mathrm{~b}$ & $463 \mathrm{a}$ \\
\hline Canapuzinho & $6,9 \mathrm{c}$ & $2,4 \mathrm{~b}$ & $15,4 \mathrm{a}$ & $13,1 \mathrm{a}$ & 22,6 a & $24,7 \mathrm{a}$ & $1248 \mathrm{a}$ & 456 a \\
\hline Pitiuba & $7,6 \mathrm{c}$ & $2,3 \mathrm{~b}$ & $16,2 \mathrm{a}$ & $14,5 \mathrm{a}$ & $18,3 \mathrm{~b}$ & $20,5 \mathrm{~b}$ & $1078 \mathrm{~b}$ & $386 \mathrm{~b}$ \\
\hline Pingo-de-ouro-1 & $7,2 \mathrm{c}$ & $2,3 \mathrm{~b}$ & $14,6 \mathrm{a}$ & $13,2 \mathrm{a}$ & $22,4 \mathrm{a}$ & $23,8 \mathrm{a}$ & $1276 \mathrm{a}$ & $359 \mathrm{~b}$ \\
\hline BR17- Gurguéia & $9,0 \mathrm{~b}$ & $2,4 \mathrm{~b}$ & $16,5 \mathrm{a}$ & $14,6 \mathrm{a}$ & $15,0 \mathrm{c}$ & $16,2 \mathrm{c}$ & $1157 \mathrm{~b}$ & $342 \mathrm{~b}$ \\
\hline Capela & $4,1 \mathrm{c}$ & $1,9 \mathrm{~b}$ & $15,2 \mathrm{a}$ & $14,6 \mathrm{a}$ & $23,9 \mathrm{a}$ & $23,0 \mathrm{a}$ & $613 \mathrm{c}$ & $338 \mathrm{~b}$ \\
\hline Epace-10 & $6,0 \mathrm{c}$ & $2,0 \mathrm{~b}$ & $16,4 \mathrm{a}$ & $13,3 \mathrm{a}$ & $21,8 \mathrm{a}$ & $24,6 \mathrm{a}$ & $1013 \mathrm{~b}$ & $320 \mathrm{~b}$ \\
\hline Santo Inácio & $5,7 \mathrm{c}$ & $1,6 \mathrm{~b}$ & $15,3 \mathrm{a}$ & $14,2 \mathrm{a}$ & $20,4 \mathrm{a}$ & $22,5 \mathrm{a}$ & $947 \mathrm{~b}$ & $246 \mathrm{~b}$ \\
\hline Tracuateua-192 & $9,8 \mathrm{a}$ & $1,3 \mathrm{~b}$ & $12,0 \mathrm{c}$ & $10,9 \mathrm{a}$ & $22,9 \mathrm{a}$ & $24,9 \mathrm{a}$ & $1024 \mathrm{~b}$ & $171 \mathrm{~b}$ \\
\hline Mean & 7,7 & 2,80 & 15,5 & 13,3 & 20,5 & 22,3 & 1167 & 466 \\
\hline C.V. (\%) & 18,7 & 7,12 & 7,05 & 10,63 & 10,48 & 10,49 & 18,60 & 39,7 \\
\hline
\end{tabular}

${ }^{1}$ Means followed by the same letter, in the column, are not different according to the Scott-Knott's test (p $\left.>0.05\right) . *$ NS - No stress, ${ }^{\#}$ WS - With stress

of available water in the soil of 40 and $60 \%$, the cultivar IPA 206 has suffered extremely negative effects on the components of production, especially on the number of pods per plant; showing that this is a quite vulnerable component of production to water deficit. According to Mendes et al. (2007), the water stress imposed in both vegetative and reproductive stages, significantly reduced the NPP produced in the cultivars Epace-10 and Seridó. The reduction of this component seems to be the main factor of decrease in grain yield of cowpea. According to Leite et al. (2000), this behavior can be explained as one of the mechanisms of drought tolerance used by this culture to seek better conditions to overcome the lack of water.

The number of grains per pod (NGP) was affected by water deficiency, and the genotypes showed significant differences between each other on this variable. These results agree with those obtained by Bezerra et al. (2003) and Nascimento et al. (2004), who found reductions in the number of pod grains with the application of water stress during the bloom and grain filling. However, Ferreira et al. (1991) working with water stress in vegetative and reproductive phases of two cultivars of cowpea, Mendes et al. (2007) studying source-sink relationships in bean-tostring subjected to water deficit and Lima (2008), found no significant differences for the NGP. According to these authors, these are characteristics of production normally resistant to changes induced by environmental stress. According to Table 1, it was observed that the genotype Tracuateua-192 showed lower number of grains per pod as far as under full irrigation and water deficit.

The one hundred grains mass (HMG) has not been reduced by the imposition of water deficit (TAB. 1). These results corroborate with those obtained by Ferreira et al. (1991), which found no significant differences for 
this variable. However, the HMG medium value of the treatment with water deficit $(22,3 \mathrm{~g})$ was slightly higher than the other one $(20,5 \mathrm{~g})$. This may be due to the smaller number of grain per pod observed on treatment with water deficit, causing an increase in grain weight. These results are according to Bezerra et al. (2003) who found a slight increase in weight of hundred seeds for the treatment with water stress during flowering in relation to treatment without water stress, although no significant difference between treatments.

Genotypes Pingo-de-ouro-1-2, Pingo-de-ouro-2, BRS Xiquexique, Tracuateua-192, Canapuzinho-2 and Canapuzinho showed the highest in the HMG under water stress conditions, but this fact did not result in higher yields; conversely, the genotype Tracuateua-192, despite having increased the HMG with the imposition of the deficit, presented the lowest productivity among all genotypes studied. Lima (2008) found no significant reductions in the value of this variable for cowpea when water stress was imposed during the reproductive period. According to Nascimento et al. (2004), this component of production reflects the relationship between source and drain. When the HMG is reduced, this indicates that production was limited at the source. This may occur due to the large number of pods, as in case of the properly irrigated treatments, or by the effect of water stress on photosynthesis or translocation of photoassimilates. The highest mass of grains may reflect a compensation for size drain limitations. These authors found results in cowpea that disagree with the data obtained in this experiment, once the one hundred grains mass in response to water deficit during the fructification was significantly reduced.

For the grain yield (GY) presented in Table 1, there are significant differences between genotypes in both water conditions. Under full irrigation, ten genotypes produced above the average, being highlighted the genotypes BRSParaguaçu, Pingo-de-ouro-1-2, CNCX 689-128G and Canapuzinho-2.

There was an average reduction of $60 \%$ in GY, when contrasted the full irrigation with water deficiency condition. Similar results were achieved by Nascimento et al. (2004) to the same crop, where it was found an average of $1,117 \mathrm{~kg} \mathrm{GY} \mathrm{ha}^{-1}$ for adequate water supply and $584 \mathrm{~kg} \mathrm{ha}^{-1}$ for imposition of water removal in the reproductive phase, resulting in 52\% GY reduction. Studies from Bezerra et al. (2003) also agree with the results of this study, which found $59 \%$ GY reduction. However, this reduction was lower than that found by Carvalho et al. (2000), who found $81 \%$ GY reduction when working on water deficit in the reproductive phase of cowpea in the greenhouse. Probably this strong reduction is due to the high environmental temperatures inside the greenhouse
( $40{ }^{\circ} \mathrm{C}$ on average). Such temperatures are detrimental to the cowpea and, especially when occurring in preflowering it causes reduction in flowering catchment resulting in decrease in the number of pods per plant and GY. The group of genotypes that produced above the average decreased by $54 \%$ in GY. In this group there is the genotype BRS-Paraguaçu, which showed 52\% average reduction. Meanwhile, in the group of genotypes with GY below the average, there was $70 \%$ GY reduction of $70 \%$, with the highest reductions being observed in genotype and Santo Inácio and Tracuateua-192, which were reduced by $74 \%$ and $83 \%$, respectively.

\section{Conclusions}

1. The water deficit reduces the leaf area index, chlorophyll content, number of pods per plant and grain yield;

2. Genotypes BRS-Paraguaçu, Pingo-de-ouro-1-2 and Pingo-de-ouro-1 presented drought tolerance behavior;

3. Genotypes Santo Inácio and Tracuateua-192 showed high sensitivity to soil water deficit, with marked reduction in leaf area, chlorophyll content and grain yield.

\section{References}

BASTOS, E. A. et al. Parâmetros de crescimento do feijãocaupi sob diferentes regimes hídricos. Engenharia Agrícola, v. 22, n. 01, p. 43-50, 2002.

BASTOS, E. A.; ANDRADE JÚNIOR, A. S. Boletim agrometeorológico do ano de 2008 para o município de Teresina, PI. Teresina: Embrapa Meio-Norte, 2009. 37p. (Embrapa Meio-Norte. Documentos, 181).

BEZERRA, F. M. L. et al. Feijão-caupi e déficit hídrico em suas fases fenológicas. Revista Ciência Agronômica, v. 34, n. 01, p. 13-18, 2003.

CARVALHO, J. A. et al. Efeito do déficit hídrico sobre o rendimento do feijão-caupi (Vigna unguiculata (L.) Walp). Ciência e Agrotecnologia, v. 24, n. 03, p. 710-717, 2000.

CONAB. Oitavo levantamento de avaliação da safra 2007/2008. Brasília, 2008. 22p. Disponível em: http://www. conab.gov.br/conabweb/download/safra8_mai2008.pdf. Acesso em: 30 out. 2009.

CORREIA, G. K.; NOGUEIRA, C. M. J. R. Avaliação do crescimento do amendoim (Arachis hypogaea L.) submetido a déficit hídrico. Revista de Biologia e Ciências da Terra, v. 04, n. 02, p. 1-7, 2004.

CRUZ, R. F. D. DA. Indução e recuperação do estresse hídrico em variedades portuguesas de milho. 2006. 182f.. Dissertação (Mestrado em Biologia do Stresse em Plantas) - Universidade do Minho, Portugal. 
FALKER. CFL1030 - clorofiLOG - Medidor Eletrônico de Teor de Clorofila. Disponível em: http://www.falker.com.br/. Acesso em 28 nov. 2008.

FERNÁNDEZ, C. J.; McINNES, K. J.; COTHREN, J. T. Water status and leaf area production in water-and nitrogen-stressed cotton. Crop Science, v. 36, p. 1224-1233, 1996.

FERREIRA, L. G. R.; COSTA, J. O.; ALBUQUERQUE, I. $\mathrm{M}$. Estresse hídrico nas fases vegetativa e reprodutiva de dois cultivares de caupi. Pesquisa Agropecuária Brasileira, v. 26, n. 07 , p. $1049-1055,1991$.

FERREIRA, V.M. et al. Crop coefficient of the cowpea in Teresina, Piauí state, Brazil. In: CONGRESSO BRASILEIRO DE ENGENHARIA AGRÍCOLA, 37, Foz do Iguaçu, Anais... Foz do Iguaçu, 2008, cd rom.

GOMES FILHO, R. R.; TAHIN, J. F. Respostas fisiológicas de cultivares de caupi (Vigna unguiculata, (L.) Walp.) eretos e decumbentes a diferentes níveis de irrigação. Engenharia na Agricultura, v. 10, n. 1-4 ,p. 56-60, 2002.

GONÇALVES, E. R. Fotossíntese, osmorregulação e crescimento inicial de quatro variedades de cana-de-açúcar submetidas à deficiência hídrica. 2008. 66f. Dissertação (Mestrado em Agronomia) - Universidade Federal de Alagoas, Centro de Ciências Agrárias, Rio Largo.

HOFFMANN, C. M.; BLOMBERG, M. Estimation of leaf area index of beta vulgaris L. based on optical remote sensing data. Journal of Agronomy \& Crop Science, v. 190, n 03, p. 197-204, 2004.

LEITE, M. L. et al. Efeitos do déficit hídrico sobre a cultura do caupi, cv. EMAPA- 821. III. Produção. Revista de Agricultura, v. 75 , n. 01 , p. $9-20,2000$.

LIMA FILHO, J. M. P. Physiological responses of maize and cowpea to intercropping. Pesquisa Agropecuária Brasileira, v. 35 , n. 05 , p. $915-921,2000$.

LIMA, A. A. F. Respostas fisiológicas de cultivares de feijão [Phaseolus vulgaris L. e Vigna unguiculata (L.) walp] submetidas à deficiência hídrica: uma alternativa para a agricultura familiar do semi-árido sergipano. 2008, $112 \mathrm{f}$. Dissertação (Mestrado em Meio Ambiente) - Universidade Federal de Sergipe, São Cristóvão.

MATSUI, T.; SINGH, B. B. Root characteristics in cowpea related to drought tolerance at the seedling stage. Experimental Agriculture, v. 39, p. 29-38, 2003.

MENDES, R. M. S. et al. Relações fonte-dreno em feijãode-corda submetido à deficiência hídrica. Revista Ciência Agronômica, v. 38, n. 01, p. 95-103, 2007.

MOUSINHO, F. E. P. A irrigação do feijão-caupi no Piauí. Comunicado Técnico, n. 05, p. 1-2, 2006.

NASCIMENTO, J. T.; PEDROSA, M. B.; TAVARES SOBRINHO, J. Efeito da variação de níveis de água disponível no solo sobre o crescimento e produção de feijãocaupi, vagens e grãos verdes. Horticultura Brasileira, v. 22, n. 02, p. 174-177, 2004.

NETTO, A. T. et al. Photosynthetic pigments, nitrogen, chlorophyll $a$ fluorescence and SPAD-502 readings in coffee leaves. Scientia Horticulturae, v. 104, n. 02, p. 199-209, 2005.

RIBEIRO, R. V. et al. Environmental effects on photosynthetic capacity of bean genotypes. Pesquisa Agropecuária Brasileira, v. 39, n. 07, p. 615-623, 2004.

SEVERINO, L.S. et al. Método para determinação da área foliar em mamoneira. Revista Brasileira de Oleaginosas e Fibrosas, v.8, n.1, p.753-762, 2004.

SUMMERFIELD, R. J. et al. The physiology cowpea. In: SINGH, S.R.; RACHIE, K.O. (Eds.). Cowpea research, production and utilization. Chichester: John Wiley, 1985. p. 66-101.

TAIZ, L.; ZEIGER, E. Fisiologia Vegetal. 3.ed. Porto Alegre: Artmed, 2004. 719 p.

VIEIRA, R. F. et al. Comportamento do feijão-fradinho na primavera-verão na zona da mata de Minas Gerais. Pesquisa Agropecuária Brasileira, v. 35, n. 07, p. 1359-1365, 2000. 